\title{
15. 太田達男，西川彰一郎：やまざくら樹皮の成分
}

朝比奈東大名礐呚授は邦童櫻樹の一種そめるよしの Prunus yedoensis Matsm の樹皮から配糖體サクラニンを發 見し ${ }^{1)}$ ，その後大島ざくら P. serrulata Lindl. var. albida Makino subv. speciosa Makino の樹皮からも之を分離し， その構造は 5,4'-Dioxy-7-methoxy-flavanon-5-glucosid であることを決定された22.

著者等は “やまざくら” P. serrulata Lindl. var. spontanea Makino の樹皮からサクラニンとは相違する淡黄色， 針狀晶の配糖體を分離した。本配糖體は之そ稀硫酸と熱于ることによつて淡黄色針狀晶，Fp $283^{\circ}$ のアグリコンと糖 に分解する.

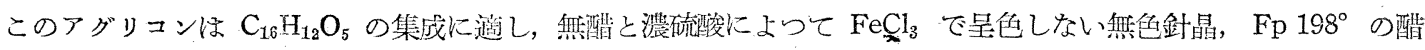

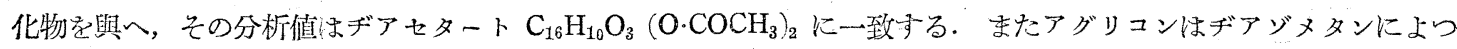
て Fp $170^{\circ}$ のメチル化體を生成する.而して本品はアカセチンをデアン゙メタンでメチル化して得たアカセチンー7ーメ テルェーテルと混融しても融熙降下を示さない.

アグリコンの集成とデアセタートの生成錐にメチル 化によるアカセテンー7-メチルエーテル郎ちアピゲニンー7, $4^{\prime}-$

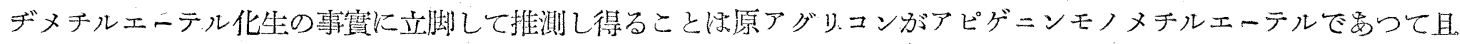
メトキシル基は 7 或は $44^{\prime}$ 位の何れかを占めていなければならぬことである.

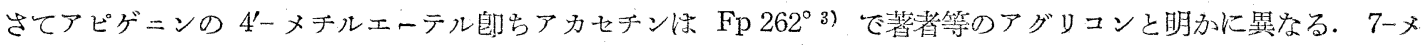
テルェーテルは “ふお゙もどき”Daphne genkwa Sieb. et Zucc. の花（芫花）に含まれゲンクワニン Genkwanin と 命名されている，ゲンクワニンは淡黄色針晶， Fp $286^{\circ}$ (合成品は Fp $283^{\circ}$ ), デアセタートは無色針晶, $\mathrm{Fp} 198^{\circ}$ で あつて $\mathrm{FeCl}_{3}$ 並に $\mathrm{Mg}$ と $\mathrm{HCl}$ による呈色反應も吾人のアグリコンと同一である.

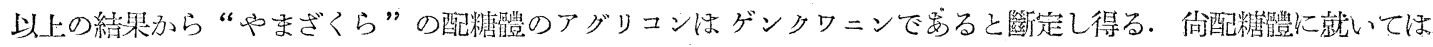
試料不足のため今後の研究にまらたい。

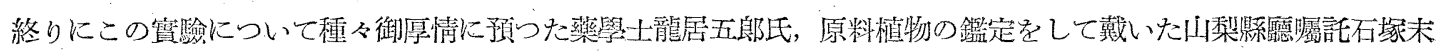
吉氏，蛽重なアカセチンの分與を賜つた東京帝大理學部服部静夫㸚授の各位に深謝の意を表する。な赫元素分析は東 大藥學科山本純子氏を煩はした。併せて謝意を表する。

\section{實 驗 の 部}

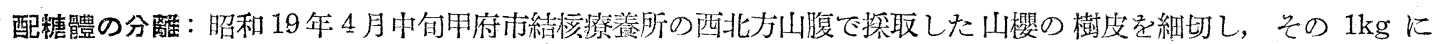
對してメタノール $4 \mathrm{~L}$ を加一時々動摇させ 2 日間放置浸诎 (2四) し, 浸夜を濾過, 蒸溜濃縮して約 $500 \mathrm{cc}$ とし約 1 ケ月放置したところ黄色結晶性の沈澱を析出した．これを吸滤し素燒板上に展ベエーテルで洗涤して原料樹皮に對

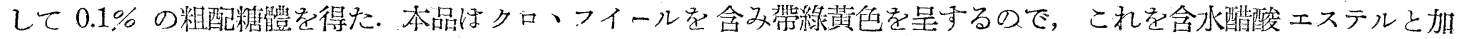

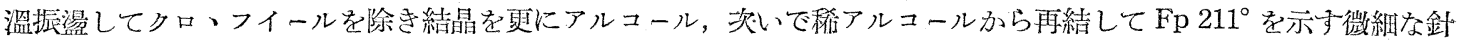

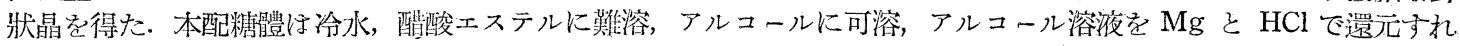
ば橙赤色灰㙷は寸。

配糖體の加水分解： $5 \%$ 旈酸 $50 \mathrm{cc}$ に試料 $1.26 \mathrm{~g}$ ，投じ，水浴上に 2 時間加熱して析出与る黃色結晶を吸滤，水洗， メタノールから再結すれ棪淡基色針晶, $\mathrm{Fp} 283^{\circ}$ のアグリコンが得られる. 本品のアルコール溶液は $\mathrm{FeCl}_{3}$ で淡褐 色, $\mathrm{Mg}$ と $\mathrm{HCl}$ で橙赤色を呈する。稀硫酸液を炭畯バリウムで中和後蒸發して得たシラップはフエーリング氏液を゙ 著しく還元する.

試料 $3.215 \mathrm{mg}: \mathrm{CO}_{2}=7.955 \mathrm{mg}, \mathrm{H}_{2} \mathrm{O}=1.305 \mathrm{mg}$.

訫算值 $\mathrm{C}_{16} \mathrm{H}_{12} \mathrm{O}_{5} \mathrm{C}=67.60, \mathrm{H}=4.22$. 實瞼值 $\mathrm{C}=67.48, \mathrm{H}=4.54$.

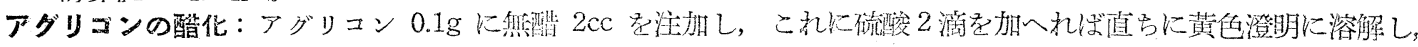

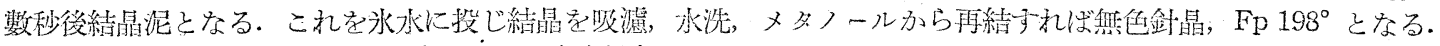
本品のアルュール溶液は $\mathrm{FeCl}_{3}$ 液にようて全く呈色しない

試料 $3.520 \mathrm{mg}: \mathrm{CO}_{2}=8.455 \mathrm{mg}, \mathrm{H}_{2} \mathrm{O}=1.405 \mathrm{mg}$.

訫算值 $\mathrm{C}_{20} \mathrm{H}_{16} \mathrm{O}_{7} \mathrm{C}=65.21, \mathrm{H}=4.34$. 辐瞼值 $\mathrm{C}=65.51, \mathrm{H}=4.46$.

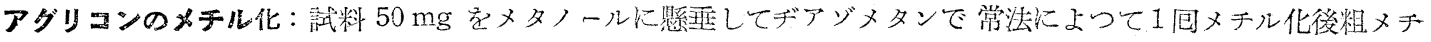

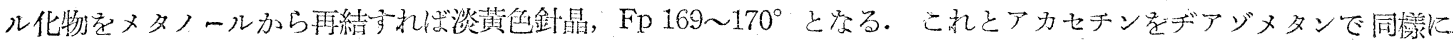

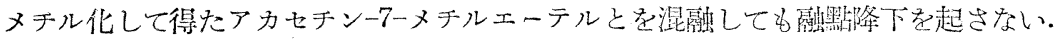

\section{東京嵲學兴門學校（昭和 22 年 3 月 1 日受理）}

1) 朝比奈: 本誌, 313,213 (明 41). 2) 朝比奈, 涤田, 犬伏: 本誌, 550, 1007 (昭 2).

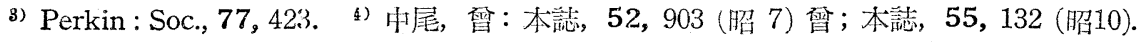

